\title{
INTRODUCTION: RE-VISITING THE AMERICAS
}

\author{
Magali Sperling Beck \\ Universidade Federal de Santa Catarina \\ Rubelise da Cunha ${ }^{* *}$ \\ Universidade Federal de Rio Grande
}

This land like a mirror turns you inward And you become a forest in a furtive lake; The dark pines of your mind reach downward, You dream in the green of your time, Your memory is a row of sinking pines.

Explorer, you tell yourself, this is not what you came for Although it is good here, and green; You had meant to move with a kind of largeness, You had planned a heavy grace, an anguished dream.

But the dark pines of your mind dip deeper And you are sinking, sinking, sleeper In an elementary world;

There is something down there and you want it told.

"Dark Pines under Water," Gwendolyn MacEwen

The lines cited above, written by the Canadian poet Gwendolyn MacEwen, reveal, in a profound way, some of the intricate challenges related to the idea of "exploration;" to a certain extent they reinstall the interconnections between inner and outer landscapes that inevitably permeate the experience of movement and discovery. In such lines, the imagery of the land as a mirror is once more presented through the speaker's recognition of the inward movement that also constitutes external searches. Yet, what might catch the reader's interest in MacEwen's poetical words is a sense of transformation and possibility: apparently, uncrossed boundaries are traversed in this representation as land and water become intertwined in the mirror composition of a "forest in a furtive lake." In this outward/inward look, there is more than confrontation. The sinking of memory seems to point towards a dive into the self, even if that might not necessarily be what the explorer is indeed looking for.

The image of this explorer's anguish dream, brought by McEwen's poem, is only one among a varied and vast range of contemporary re-readings of dislocation and conquest, particularly in the contexts of writings produced in the Americas. Even if some critics, such as James Clifford, have suggested that "we have always been on the move and have been for centuries, dwelling in traveling" (2), to inhabit spaces of dislocation or to reflect upon the unbalanced power relations involved in the crossing of boundaries still raise important questions about how subjects approach and represent themselves and others in cultural encounters. MacEwen's metapoetical piece offers the reader not only an opportunity to reflect about the acts of seeing, imagining, and creating, but also to elaborate on the possibilities of re-discoveries. In the poem, the explorer's enterprise is characterized through the use of words such as "largeness" or "heavy grace," which are

\footnotetext{
${ }^{*}$ Magali Sperling Beck holds a Doctoral Degree in English from the University of Alberta, Canada. She is an Adjunct Professor of Literatures in English at the Modern Languages Department and at the Graduate Program in English, both at Universidade Federal de Santa Catarina. Her research interests include Canadian and American literature, travel writing, inter-American crossings. Her recent publication includes articles on travel writing by women in the Americas. E-mail: magalisperling@gmail.com

** Rubelise da Cunha is Associate Professor of English and Vice-Coordinator of the Center for Canadian Studies at the Federal University of Rio Grande (FURG), Brazil. She developed research on genre theory and Indigenous theatre as a Visiting Scholar at Laurentian University (Sudbury, Canada, 2008-2009). Her research was financed by CAPES. She is a member of ANPOLL in the research group on Transculturality, Language and Education. Her research fields include postmodern and postcolonial literatures, comparative studies (Brazil-Canada) and Indigenous literatures. E-mail: rubelise@hotmail.com
} 
juxtaposed to "dark pines going deep." In this mirrorlike landscape, exploration might lead to unexpected meanings, which, more often than not, reconnect us with the past, with the varied sites of representation. It is in this "re-mapping" of what is "in there and wants to be told" that lie the reflections present in this thematic issue of Ilha do Desterro.

The crossing of borders and the exploration of new routes, meanings and definitions have permeated the history of the Americas even before the arrival of the first European colonizers. Yet, it was with colonization that the question of how to represent the "new" and "different" other became so emblematic. This question is, still today, one of the most intriguing questions in critical and literary debates as writers continue to address the issue of cultural representation in their works, re-creating new meanings for the varied experiences of cultural encounters in the Americas. A great part of these recreations could be approached as "re-discoveries" of self and other in historical and geographical dislocations, which allow contemporary writers and artists to negotiate the representation of "difference," be it in terms of cultural, gendered, social and/or geopolitical identities. Thus, the articles collected in this issue of Ilha do Desterro discuss how recent literary, cultural and critical productions offer new and challenging ways to view such "re-discoveries."

The focus on a continental perspective, more than attempting to forcefully shape a single view on the multiplicity of voices North and South of the Americas, hopes in fact to shed some light on the points of intersection and communication as well as on the diversity of cultural productions in the continent. In Brazil, writers such as Zilá Bernd and Eurídice Figueiredo ${ }^{1}$ have been showing, since the end of the 1990's, that an inter-American comparative perspective addressing issues of identity, resistance, ethnicity, gender, among others, enables a solid and necessary debate on the varied colonial and post-colonial experiences in the Americas. Even if not directly theorizing about possible comparative inter-American approaches, the articles collected here continue to instigate this much-needed debate. In this collection, scholars revise literary and cultural manifestations from various locations, such as Brazil, Canada, the Caribbean, Ecuador, and the United States in a renewed effort to reflect about historical legacies and identity issues that cross different frontiers in the American continent.

The volume, thus, opens with Laura Beard and Daniel Hopkins's "Indigenous: It Depends How You Look at It. What You Call It. How You Live It," which invites us to reflect about identities in an InterAmerican perspective. Beard and Hopkins state that within that oddly shaped landmass of the Americas, arguably the most "misidentified, mislabeled, and misrepresented" of all are Indigenous peoples. They use examples from contemporary Anishinaabe artist Rebecca Belmore and Spiderwoman Theatre to explore how contemporary Indigenous artists in the Americas negotiate the representation of Indigenous identities, identities which are always performed and entangled in a mesh of geographical locations, cultural practices and ideological borders. Beard and Hopkins argue that Native artists and authors participate in a larger community of voices discussing what it means to be Indigenous in the Americas and what ethical responsibilities or commitments to community are entailed in and by their work.

In "Decolonizing Straight Temporality through Genre Trouble in Edwidge Danticat's The Farming of Bones," Eliana Ávila engages in a discussion about how Danticat's fictional metatestimonio challenges a normative chronopolitics by reinstalling the impact of the Trujillo genocide of Haitian workers in the Dominican Republic. Thus, The Farming of Bones is read in the context of the Latin American testimonio, allowing Ávila to demonstrate the significance of Dandicat's historiography not only to the Caribbean region, but also to other sites of military intervention and genocide in the Americas.

Such decolonizing historiography is also present in other articles from the volume. In María Rocío Cobo Pinero's and in Denise Almeida Silva's contributions, for example, the politics of representation in relation to black identities is foregrounded. In “Gayl Jones's Corregidora and Song for Anninho: Historical Revision, Female Diaspora, and Music," Pinero recovers Gayl 
Jones's work and her uses of music and of the oral tradition as ways to recreate the history of slavery and the varied experiences of black women in the Americas. Instead of focusing only on the history of slavery in the United States, Jones sets her writing in places such as Brazil, a fact which leads Pinero to discuss how Jones's novels enable the writer to establish an inter-American dialogue. Black identity is also revisited in Denise Almeida Silva's "De Epistemicídio, (In)visibilidade e Narrativa: Reflexões sobre a Política de Representação da Identidade Negra em Cadernos Negros." In this article, Silva focuses on an analysis of the literary and cultural productions present in Cadernos Negros, which, according to the author, combat black invisibility in Brazil as well as what theoreticians such as Boaventura de Souza Santos call epistemicide, or the lack of cognitive justice in face of non-hegemonic kinds of knowledge.

The experiences of the so-called cultural minorities in the United States are approached in two of the articles from this collection. In "The Intertext of History and Literature in Face of an Angel, a Postmodern/Postneocolonial Novel by Denise Chávez," Lana Beth Araújo and Peônia Viana Guedes explore the intricacies of history and fiction in Chávez's novel in order to recontextualize the Chicano and Chicana experience during three different but relevant historical moments in the United States. The literary production of another minority group in the U.S. is the focus of Gláucia Renate Gonçalves and Cláudio Bragàs "A Thousand and One Voices: Re-reading Scheherazade in Contemporary Arab-American Fiction." In this article, Gonçalves and Braga recover the trajectory of Arab-American writers as a way to challenge their marginal position in relation to mainstream American writing; they also demonstrate how contemporary writers from the Arab diaspora in the United States have worked towards the disruption of Western essentialist stereotypes, mainly in relation to the depiction of Arab women. The reconfiguration of Scheherazade as a storyteller is central to Gonçalves and Braga's analysis.

In "Fronteiras transplatinas nos contos de Sergio Faraco", Andrea Cristiane Kahmann and Anselmo Peres Alós discuss how the crossing of geographical borders is central for the life and the literature of the pampas in South America. The authors propose a transnational reading of Sergio Faraco's short stories, from a perspective that articulates cultural and translation studies, and explore how Faraco elaborates a narrative from the border, and not about the border. They demonstrate how the decentered characters of Faraco's stories and their sense of non-belonging corroborate the pampas as a space of ambiguity and ambivalence and anticipate the dark effects of a globalized society.

The articles by Albert Braz and Brenda Carlos de Andrade close the volume, contemplating representations of selves and others in the crossing of borders or of gazes in the Americas. In "The Accidental Traveller: Priscila Uppal's Search for Her Fugitive Brazilian Mother," Albert Braz explores how Priscila Uppal's 2013 memoir Projection: Encounters with My Runaway Mother illustrates that accounts of journeys to other countries are not always primarily motivated by global politics but rather by family dynamics. Braz discusses how Uppal's re-discovery of Brazil is permeated by her feeling of resentment, since this is the birthplace of the mother who abandoned her as a child. Brenda Carlos de Andrade's "Imagens de Presentes/Fantasmas do Passado" presents and analyzes a selection of photographs depicting different SouthAmerican "scenes", which were taken by different artists in varied historical moments. Through the compilation and discussion of such images, Andrade demonstrates how the ethnographical posture in past representations is revisited and reconstructed in the work of the contemporary photographer Lucía Chiriboga. In the light of all the other contributions to this volume, the kind of re-signification elaborated in Andrade's discussion, as well as in Braz's reading of Uppal's memoir, once more demonstrates the significance of a continuous reflection about North and South American re-discoveries.

The review section of this volume presents Tacel Coutinho Leal's considerations about Human Rights and Immigration, an anthology edited by Ruth RubioMarín which explores the frontier that ties the question of human rights to immigration in the contemporary world. Luciana de Abreu Jardim's review of Pensar em 
não ver: escritos sobre as artes do visível (1979-2004) discusses the book organized by Ginette Michaud, Joana Masó and Javier Bassas which presents Marcelo Jacques de Moraes's translation of Jacques Derrida's interviews, conferences and other fragmented texts on the visual arts.

The multiple re-discoveries of the Americas enhanced by the articles published in this issue of Ilha do Desterro represent a collaborative construction of knowledges from North to South. We would like to kindly thank the authors for their partnership in this journey into memory and the self, and into our own otherness as inhabitants of the American continent.

\section{Note}

1. In the chapters "Americanidade e Americanização" e "Literatura Comparada e Estudos Culturais: Por um Comparativismo Interamericano," both Zilá Bernd and Eurídice Figueiredo, respectively, recuperate the trajectory of inter-American comparative studies developed not only by them, but also by other Brazilian scholars. For complete bibliographical references, see Works Cited.

\section{Works Cited}

Bernd, Zilá. "Americanidade e Americanização." Conceitos de Literatura e Cultura. Eurídice Figueiredo (Ed.). Niterói: EDUFF, 2012.

Clifford, James. Routes: Travel and Translation in the Late Twentieth-Century. Cambridge, Massachusetts: Harvard University Press, 1997.

Figueiredo, Eurídice. "Literatura Comparada e Estudos Culturais: Por um Comparativismo Interamericano." Representações de Etnicidade: Perspectivas Interamericanas de Literatura e Cultura. Eurídice Figueiredo. Rio de Janeiro: 7Letras, 2010.

MacEwen, Gwendolyn. "Dark Pines Under Water." Canadian Poetry Online at University of Toronto Libraries, 2000. Web. 18 Aug. 2014. http://www.library. utoronto.ca/canpoetry/macewen/poem7.htm 